\title{
AN EMPIRICAL STUDY OF THE DETERMINANTS OF SYDNEY'S DWELLING PRICE
}

\section{ANGELO KARANTONIS and XIN JANET GE University of Technology, Sydney}

\section{ABSTRACT}

Australian dwelling prices have increased substantially since the early 1990s, making housing less affordable for many potential home buyers. This study aims to identify the main determinant factors that drove the dwelling prices upwards in Sydney from 1992 to 2006. The findings suggest that real household income, dwelling completions, speculative investment and real interest rate are the main variables influencing the increase of dwelling prices in Sydney. Amongst the findings is that there is a need for policy makers to improve the supply of dwellings to accommodate the growing demand of housing in Sydney.

Keywords: Housing prices, dwelling prices, housing demand and supply, affordability, multiple regression analysis

\section{INTRODUCTION}

Since the early 1990s, Australia has witnessed sustained economic growth and an era of low inflation and interest rates relative to the previous decade. Paralleling the strong economy, Australian residential property prices have increased substantially and in particular in Sydney, as depicted in Figure 1, increasing from \$140,300 in March 1992 to $\$ 437,100$ in June 2006, or 212 percent (Australian Bureau of Statistics, 2006; Christopher, 2006). The substantial increase in dwelling price has had the effect of making home ownership in Sydney less affordable for many potential buyers. 
Figure 1: Dwelling prices in Sydney (1992-2006) (Source: ABS Australia, various issues)

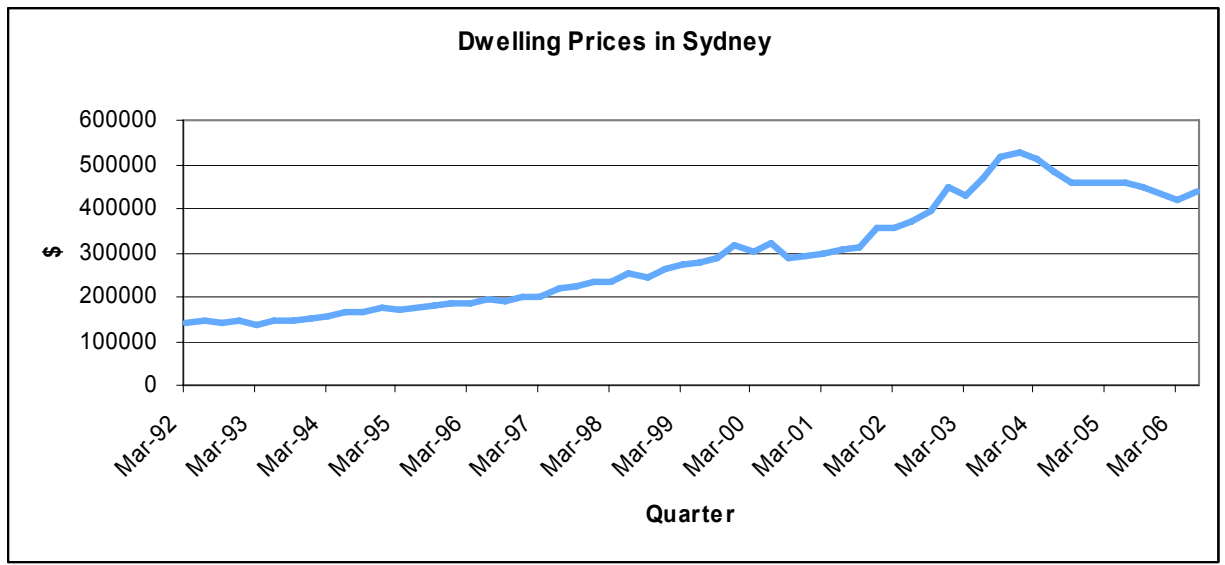

HIA (HIA, 2007) measures affordability by deriving an Affordability Index which measures the ratio of net household income to net qualifying income for an 80 percent loan of the Sydney median dwelling price. The higher the ratio, the more affordable and vis $a$ vis, the lower the ratio, the less affordable. Figure 2 shows the HIA affordability index and as can be noted, the index has dropped from 119.1 in March 1992 to 86.0 in June 2006, after having reached as low 65.8 in December 2003. Thus, it is of interest to analyse the main determinants of dwelling prices in Sydney and to make, where possible, recommendations to policy makers.

Figure 2: Australian Housing Affordability Index (Source: HIA various)

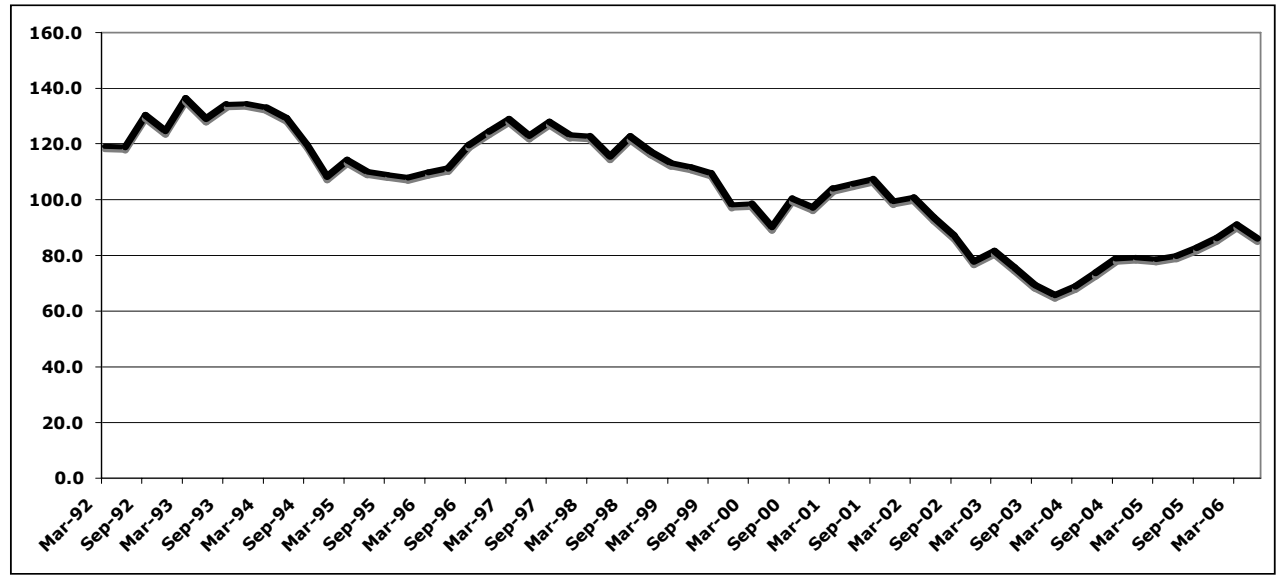


Accordingly, the aim of this paper is to identify the main determinants that drove the Sydney dwelling price on this long term upward cycle. In order to achieve the objective, the research begins by identifying the main variables that influence demand for and supply of dwellings through a literature review and then applies a quantitative analysis. The paper then discusses the findings before making some recommendations and concluding remarks.

\section{LITERATURE REVIEW}

Like all markets, the dwelling market is determined by demand and supply factors and as (Dusansky \& Wilson, 1993) pointed out, the housing market is not only a shelter for householders, but is also an investment instrument. Stead (2006) added that demand and supply imbalance can fuel dwelling price growth, whilst Reichert (1990) suggested that national economic factors as well as local factors have a unique impact on dwelling demand and therefore on dwelling prices. Ley and Tutchener (2001) found that supply factors including vacancies, housing starts and interest rate also have an effect on dwelling prices.

The relationship between household income and dwelling demand has long been of interest to economists and policymakers and accordingly, there is a vast amount of literature addressing this field. It is generally accepted that a higher level of economic growth and higher employment rate will result in a higher level of household income (Keynes, 1936). This in turn results in a higher demand, as Goodman (1989) indicated that an increase in income implies an increase in demand for housing. Further research by Goodman (2002) found that income and value-rent measures in different years have separable and significant impacts on housing demand. Tse and Love (2000) also concluded that rising income increased the demand for higher quality accommodation and environmental amenities. However, Gallin (2003) tested the long term relationship between income and house prices in USA and found that the data did no support the view of co-interaction between house prices and income.

Millington (1994) and Grimes et al (2004) expressed that economic growth is a significant factor in contributing to the rising house values. A study of the regional economics in California by MaCurdy (2005) found that employment growth is an important factor in determining housing demand. Osborne (2006) also found that the current increase in UK housing prices was due to the strong economy and high employment activity. Barker (2003) in his UK study also noted that a stable macroeconomic environment is one of the key factors that affects the housing demand changes.

Expectations can also play an important role in the demand for property. Expectations determine current market prices (Ganesan, 1984), with the housing demand curve being dependant on price expectations (Dusansky \& Wilson, 1993). In a study of UK house prices, Muellbauer and Murphy (1997) identified real interest rates and income 
expectations as the major variables. In a US study, Painter and Redfearn (2002) focused on the role of interest rates on homeownership rates and housing stock and found that whilst interest rates had a small direct role in changing homeownership rates, housing starts were sensitive to changes in the rate of interest. Undertaking a study in Singapore, Lum (2002) developed a structural model of house price determination and presented new evidence on the impact of market fundamentals and public policy variables on house price. Lim's conclusion was that low mortgage costs and economic growth were the two main factors influencing the Singapore property market from 1975 to 1995.

By its nature, higher expectations induces speculation. Speculation has been considered as a possible determinant of housing prices by a number of authors, including Case and Shiller (1990), Ito and Hirono (1993), and Levin and Wright (1997a). Speculation occurs when over a short period of time, prices are increasing more rapidly than the expected rate. In Hong Kong, Ho (2000) analysed housing prices and included a speculative demand variable, derived by taking the deviation from the estimated long-term trend line of the real housing price index. Ho's result suggested speculative demand had statistical significance with a coefficient of 0.93 . This implies that a rise in housing prices will stimulate speculative demand, which in turn will result in higher housing prices.

Demographic variables such as family size and age composition are also major determinants of household consumption patterns (Pollak \& Wale, 1981). As net overseas migration is a critical determinant of the rate of new household formation, it also can be a determinant of demand for housing. Bloch (1997) deemed that immigration can be a major factor in inducing wild property market swings and noted that between late 1993 and early 1996, an overseas immigration boom into Auckland attributed to Auckland's housing price increase of up to 100 percent in some of its suburban areas.

Turning to the supply side, a review of housing supply in the UK, Barker (2003) noted that demand side factors alone could not explain the high rate of house price growth and that responsiveness of low house supply affected the rising trend in house prices. Similarly, in a Hong Kong study, Hui and Ho (2002) adopted a time series regression method to identify the correlation between housing price, land supply and land use planning and found that there was no clear relationship between the amount of land sold and the actual housing supply.

The supply of owner occupied dwellings arises from three modes: existing dwellings, newly constructed dwellings, and dwellings converted from rental occupied to owner occupied property (Megbolugbe \& Chao, 1993). Dwelling supply, according to Maclennan (1982), is the rate at which new supplies enter the market and this can vary according to the completion rate of new dwellings or by the raising or lowering of the rate of flow of dwelling services from existing stocks of housing. The short term allows variable factors of production to be varied; in the long term, all inputs may change. Limited supply of dwellings in local markets can exaggerate house price movements as a shortage of properties forces up market values. Restrictions on the supply of building land 
will have the same effect. However in the long term, a high level of demand for housing leads to an expansion in dwelling building and an increase in the available market supply.

\section{A REDUCED-FORM OF HOUSE PRICE MODEL}

Research into house price models has been based on the stock-flow model, which has been widely used in macroeconomic studies of the housing market. In accordance with the studies covered in the literature review, a number of scholars have applied such models. For instance, DiPasquale and Wheaton (1994), Abraham and Hendershott (1996), Reichert (1990) and Malpezzi (1999) all used reduced-form function, linear regression and error correction frameworks in their models.

The reduced-form function is derived from a demand equation and a supply equation. This is listed as follows:
Demand function $Q_{d}=f\left(x_{i}, y_{i}, z_{i}, t\right)$
$(t=1,2,3 \ldots)$
Supply function $Q_{s}=f\left(v_{i}, t\right)$
$(t=1,2,3 \ldots)$

where $x_{i}$ indicates the macroeconomic variables such as GDP, interest rates;

$y_{i}$ indicates the housing-related variables such as household's income;

$z_{i}$ indicates the demographic variables such as population and migration;

$v_{i}$ indicates the supply variables such as dwelling unit completion;

$t$ indicates the given time period.

Under an assumption of supply-demand equilibrium within the given period, i.e., $Q_{d}=Q_{s}$, the function (1) and (2) give a reduced-form price function:

$$
\begin{array}{ll}
P_{t}=f\left(Q_{d}, Q_{s}, t\right) & (t=1,2,3 \ldots) \\
P_{t}=f\left(x_{i}, y_{i}, z_{i}, v_{i}, t\right) & (t=1,2,3 \ldots)
\end{array}
$$

The functional form in Equation (4) can be converted into a linear equation suitable for estimation by standard multiple regression techniques. Accordingly, the multiple regression equation for house price becomes:

$$
P_{t}=\beta_{0}+\beta_{1} x_{i t}+\beta_{2} y_{i t}+\beta_{3} z_{i t}+\beta_{4} v_{i t}+\varepsilon_{t}
$$

where $P_{t}$ is dwelling price and is the dependent variable for this study; $\beta_{0}$ represents the intercept; $\beta_{1} \ldots \beta_{4}$ represent the regression coefficients (or elasticities) associated with the respective explanatory (independent) variables; and $\varepsilon_{t}$ is a disturbance term for quarter $t$, where $\varepsilon_{t} \sim \mathrm{N}\left(0, \sigma^{2}\right)$. The expected sign of $\beta$ can be positive or negative depending on the significance of the independent variables. 


\section{DATA COLLECTION AND PROCESSING PROCEDURES}

Unless specified, quarterly time-series data was collected from secondary sources for the period March 1992 to June 2006. The description of variables employed is listed at Table 1. Sydney median dwelling prices were derived by the Real Estate Institute of NSW (REI), housing loan standard interest rates were collected from the Reserve Bank of Australia (RBA), household incomes were provided by Housing Industry Association (HIA) and all other variables are from the Australian Bureau of Statistics (ABS). The Australia net migration series data has been used as proxy in this study. A variable 'speculation' was added and was derived using the average and standard deviation of the dwelling price. Where the price increase is greater than the standard deviation from the mean, speculation is indicated and measured as ' 1 ', and where price increase is less than the standard deviation from the mean, no speculation exists and is indicated as ' 0 '.

Table 1: Description of variables

\begin{tabular}{|l|l|l|l|l|}
\hline Name & Definition & Measure & Source & Transform \\
\hline LRMSP & $\begin{array}{l}\text { Median Dwelling Prices } \\
(\text { Sydney) }\end{array}$ & $\$$ & REI & Log, Real \\
\hline LRHIM & $\begin{array}{l}\text { Mean Household Incomes } \\
\text { (Sydney) }\end{array}$ & $\$$ & HIA & Log, Real \\
\hline LHC & $\begin{array}{l}\text { Dwelling Completions (NSW- } \\
\text { houses) }\end{array}$ & No & ABS & Log \\
\hline SPEC & Speculation (Sydney) & 0, or 1 & Derived & $>$ sd = * or 0 $^{\circ}$ \\
\hline RHLP & Housing Interest Rate & $\%$ & RBA & Real \\
\hline LNM & Net Migration (Australia) & No & ABS & Log \\
\hline
\end{tabular}

All data was analysed and manipulated in order to make it more suitable for quantitative analysis. Where the variables median price, household income and interest rates were transformed into real terms, the variables were adjusted to take into account the rate of inflation.

The collected data was tested to see a) whether the individual data follows a normal distribution, and $b$ ) whether the independent variables are linearly related to the dependent variable. This required an analysis of the data to see whether the time series data are stationary. A time series is said to be stationary if the mean and autocovariance of the series do not depend on time (QMS, 2004) and to test this, the unit root test, including the ADF (Augmented Dickey-Fuller) test was employed using Eview software. All variables were tested and their unit roots show that the time series data of all the variables are stationary at a $5 \%$ level of significance.

To test whether the dependent and independent variables are correlated, a correlation matrix was used which shows the coefficients of correlation between all pairs of variables. 
Table 2 depicts the correlations between dependent and independent variables are significant at the $1 \%$ level. As can be noted, the dependent variable, real medium dwelling price has a strong positive correlation with real household income, speculation and net migration. On the other hand, real medium dwelling price has a negative correlations with real housing interest rates and dwelling completions.

Table 2: Correlations between dependent (LRMSP) and independent variables

\begin{tabular}{|c|c|c|c|c|c|c|c|}
\hline & & LRMSP & LRHIM & SPEC & LNM & LHC & RHLP \\
\hline LRMSP & $\begin{array}{l}\text { Pearson } \\
\text { Correlation }\end{array}$ & 1 & & & & & \\
\hline LRHIM & $\begin{array}{l}\text { Pearson } \\
\text { Correlation }\end{array}$ & .847 & 1 & & & & \\
\hline SPEC & $\begin{array}{l}\text { Pearson } \\
\text { Correlation }\end{array}$ & .674 & .324 & 1 & & & \\
\hline LNM & $\begin{array}{l}\text { Pearson } \\
\text { Correlation }\end{array}$ & .434 & .368 & .206 & 1 & & \\
\hline LHC & $\begin{array}{l}\text { Pearson } \\
\text { Correlation }\end{array}$ & -.468 & -.399 & -.262 & -.465 & 1 & \\
\hline RHLP & $\begin{array}{l}\text { Pearson } \\
\text { Correlation }\end{array}$ & -.734 & -.771 & -.275 & -.424 & .341 & 1 \\
\hline
\end{tabular}

\section{EMPIRICAL RESULTS AND VALIDATION}

Several models were tested with the results of the three most significant models shown in Table 3. For all these models, the dependent variable is the transformed Sydney median dwelling real price.

Table 3: Regression results (Dependent variable: LRMSP, $\mathbf{n = 5 7}$ )

\begin{tabular}{|c|c|c|c|c|c|c|c|c|c|}
\hline \multirow[t]{2}{*}{ Variable } & \multicolumn{3}{|c|}{ Model_1 } & \multicolumn{3}{|c|}{ Model_2 } & \multicolumn{3}{|c|}{ Model_3 } \\
\hline & Coefficient & t-test & Sig. & Coefficient & t-test & Sig. & Coefficient & $\mathrm{t}$-test & Sig. \\
\hline LRHIM & 1.9376 & 14.258 & .0000 & 1.9438 & 11.510 & .0000 & 1.6412 & 14.205 & .0000 \\
\hline LHC & -0.5398 & -5.435 & .0000 & -0.4752 & -3.631 & .0006 & -0.2692 & -3.038 & .0037 \\
\hline SPEC & 0.1652 & 7.183 & .0000 & & & & 0.1538 & 8.610 & .0000 \\
\hline LRLP & & & & -0.0317 & -4.594 & .0000 & -0.0277 & -6.117 & .0000 \\
\hline $\begin{array}{l}R^{2} \\
\text { Adj. } R^{2} \\
\text { DW } \\
\text { Sig. }\end{array}$ & \multicolumn{3}{|l|}{$\begin{array}{l}0.79845 \\
0.79099 \\
0.72704 \\
.0000\end{array}$} & \multicolumn{3}{|l|}{$\begin{array}{l}0.71661 \\
0.70612 \\
0.85805 \\
.0000\end{array}$} & \multicolumn{3}{|l|}{$\begin{array}{l}0.88186 \\
0.87517 \\
1.4345 \\
.0000\end{array}$} \\
\hline
\end{tabular}

Model 1 tested three variables, namely household income, dwelling completion and speculation and the results indicate that all three variables are statistically significant. With an adjusted $\mathrm{R}^{2}$ of 0.79 , the model explains 79 percent of the variation in the median dwelling price in Sydney. However, the Durbin Watson test suggests there is a serious autocorrelation problem in the model. 
Similarly, model 2 also tested three variables, household income, dwelling completion and real interest rate and once again all three were shown to be statistically significant in the model. The adjusted $\mathrm{R}^{2}$ shows that the model explains about 71 percent of the variation in the median dwelling price in Sydney. However, whilst the Durbin Watson test improved, it still shows the model to have a serious autocorrelation problem.

Finally, model 3 included four independent variables, household income, dwelling completion, real interest rate and speculation, and the results show that all four variables are statistically significant. The adjusted $\mathrm{R}^{2}$ has improved, indicating that 87.5 percent of the variation in the median dwelling price in Sydney is explained by the independent variables. The Durbin-Watson (DW) has also improved to 1.434, indicating that firstorder autocorrelation in the residuals has been eliminated.

Clearly model 3 is the preferred model. The results of the model show that a one percent increase of household income will induce a 1.64 percent increase in dwelling prices and likewise a one percent increase in speculation will increase the dwelling price by 0.15 percent. On the other side, a one percent increase of dwelling completion will approximately decrease dwelling price by 0.27 percent and for every one percent increase in real interest rates, the percentage change in dwelling prices decreases by 0.03 percent.

The standard error of regression of 0.05 for model 3 shows that the model is linear and is likely to also be an effective analytical and forecasting tool. Figure 3 shows the comparison of the original median dwelling price series and the predicted model. As can be noted, the trends of the two time series appear to be very similar over the period. However, there are some discrepancies, for example, the periods of December 2000, June 2002 and June 2005. This indicates that there is some other determinant/s having an impact for those periods, which is not explained by the model. 
Figure 3: The trends of the original trend and the derived model 3

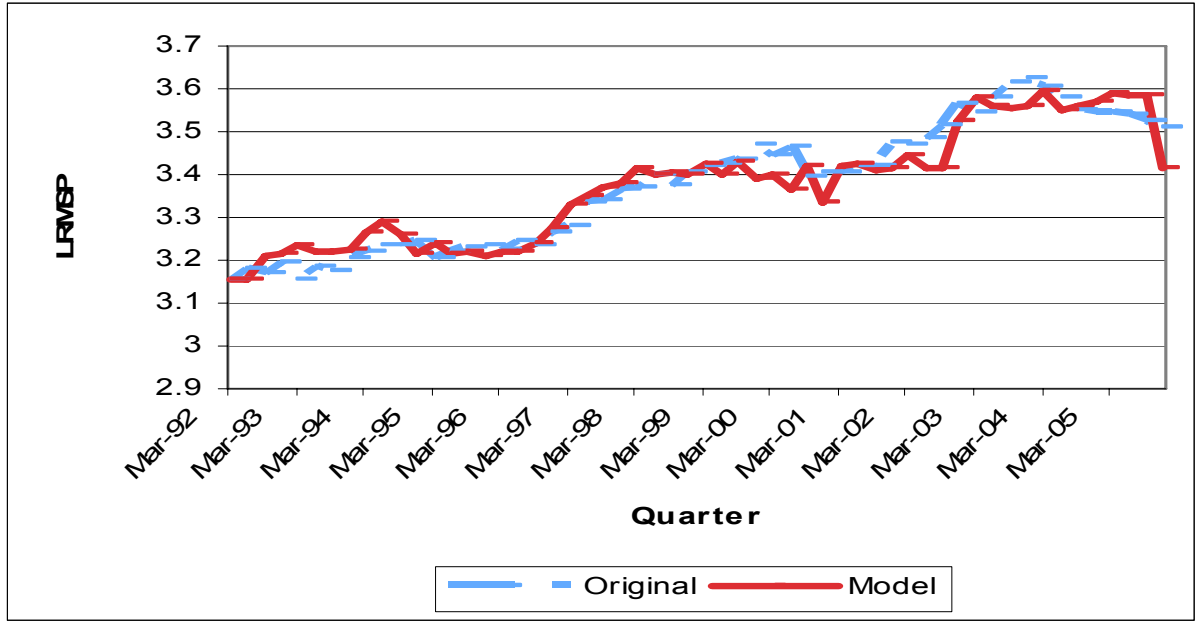

Tests for non-normality, heteroscedasticity, and non-independence of the error variable were undertaken for model 3 and are shown in Appendices 1,2 and 3 respectively. The non-normality test was carried out by producing a histogram (see Appendix 1) of the residuals to see if the error variable appears to be normally distributed. As the histogram suggests that the error variable is approximately normally distributed, the model satisfies the tests. To test the heteroscedasticity, the residuals were plotted against the predicted values of the original dwelling price (see Appendix 2). The figure shows that there is no apparent change in the variation of the residuals. Finally, the non-independence of the error variable is often used to detect autocorrelation by graphing the residuals against the time periods. If a pattern emerges, it is likely that the independence requirement is violated. The figure (see Appendix 3) shows no pattern and therefore suggests that it represents independent errors. Based on the above analysis, it suggests that model 3 is a valid model.

\section{DISCUSSION}

The three regression models developed in this paper suggest that the average household income, dwelling completions, speculation and the real housing interest rate are the main variables influencing the changes of dwelling prices in Sydney. The present findings of house price determinants demonstrate a consistency with findings from the literature; household income (Brown, Song, \& McGillivray, 1997; Dieleman, Clark, \& Deurloo, 2000; Reichert, 1990); dwelling completions (Omar \& Ruddock, 2002; PCA, 2007); speculation (Ito \& Hirono, 1993; Levin \& Wright, 1997a); and interest rate (Peng \& Wheaton, 1994; Tse, Ho \& Ganesan, 1999). 
ABS (2007) shows that Australia's real net national disposable income per capita rose by 50 percent between 1991/92 and 2005/06 and real national net worth per capita grew by 10 percent between mid 1992 and mid 2006. These increases lift the borrowing capacity of households and thereby fuel demand to purchase dwellings, which in turn puts upward pressure on dwelling prices. In a similar way, a lower interest rate fuels demand. The mortgage interest rate for the period 1997 to 2006 averaged 7 percent, which was relatively lower when compared to the pre-1997 average as depicted in Figure 4. Lower mortgage rates imply lower repayments and this again encourages the purchase of dwellings and increases the pressure on dwelling prices.

\section{Figure 4: Real rate of interest for housing (Source: RBA, 2007)}

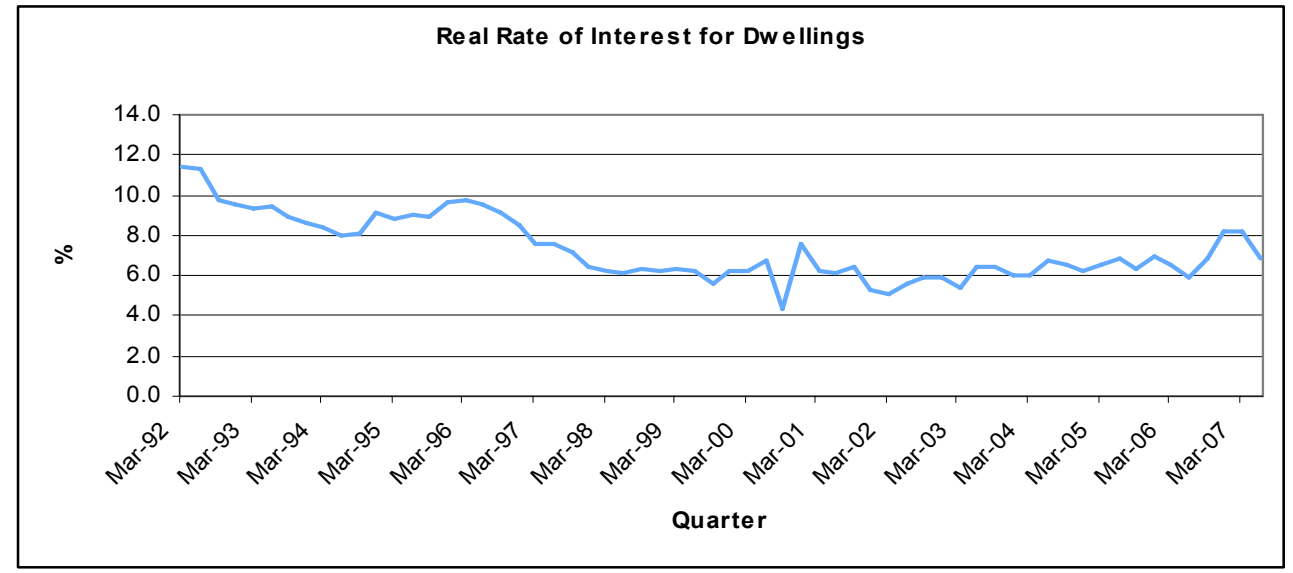

The predominance of existing housing makes the amount of housing supply quite fixed in the short-term and any new supply is time-consuming, as confirmed by Maclennan (1982) who pointed out that it takes a long time to complete a new dwelling unit. This short-term inelasticity of housing supply explains why housing supply usually lags behind demand whenever there is a sudden increase in housing demand (Omar \& Ruddock, 2002). In New South Wales, the dwelling completions have been deficient in meeting the underlying demand for housing. The deficiency has deteriorated further since 2000, as shown in Figure 5 and this also has contributed to the substantial increase of dwelling prices. 
Figure 5: Underlying demand and dwelling completion (Source: ABS, various issues)

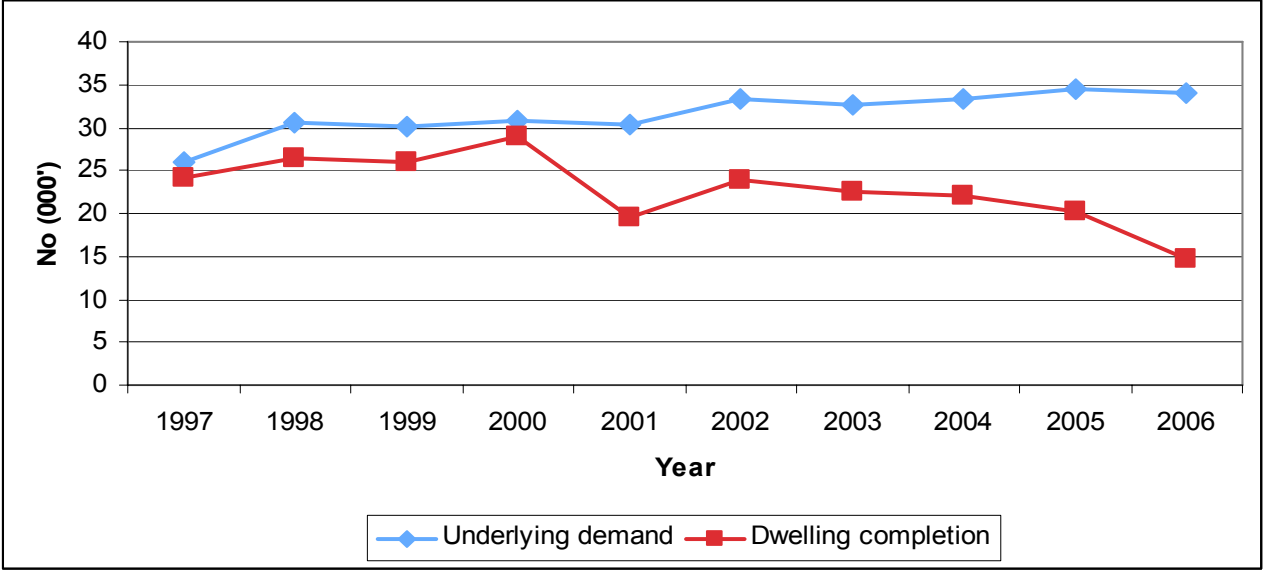

The PCA (2007) identified that there is a worsening demand supply imbalance in Sydney due to a number of factors, but most importantly the lack of long term supply of land to allow new dwelling completions as shown in Figure 6. Figure 6 shows the availability and underlying dwelling requirements of land for Sydney from 2001 and projected to 2026. As can be seen, clearly, there is a need for governments to release more land for the purpose of development.

Figure 6: PCA forecast of land supply (Source: PCA, 2007)

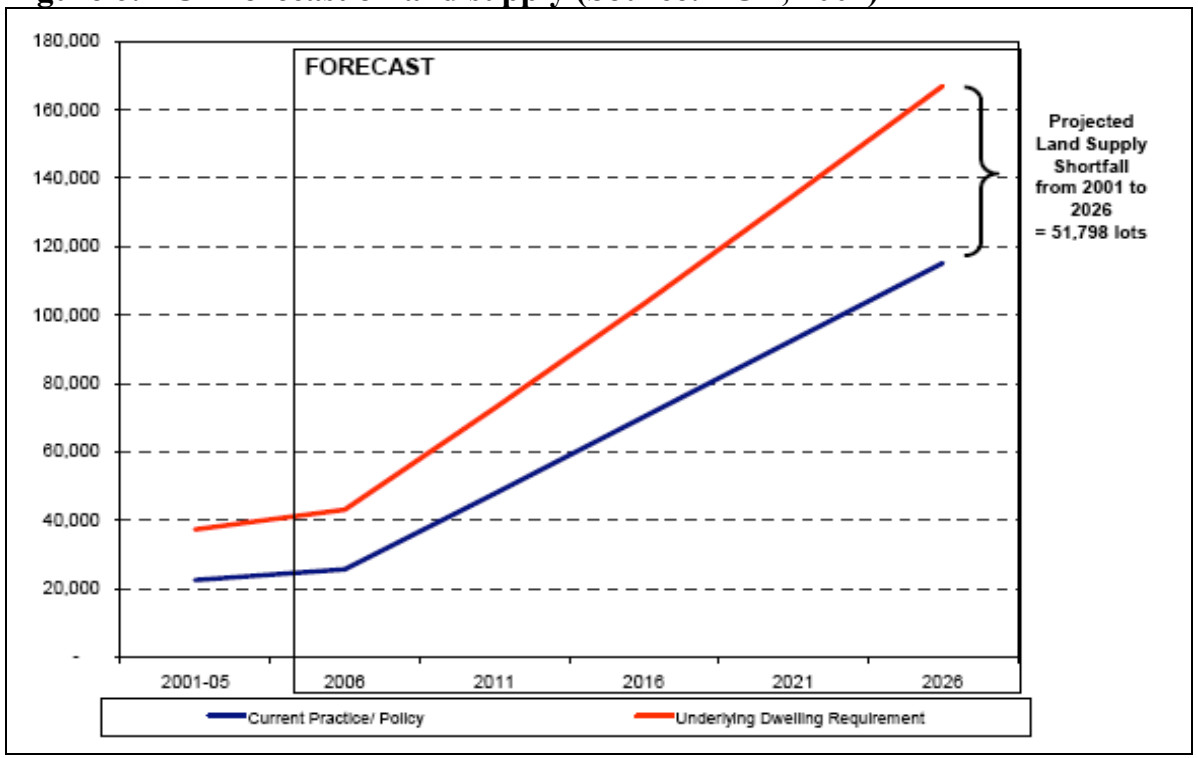


Finally, whilst demographic factors were shown not to have statistical significance for determining dwelling price in this study, it is still an important factor as the correlation test demonstrates that there is a strong correlation between the net migration and dwelling prices. In Australia, new overseas migration rose substantially to an annual average of 114,900 persons from 2000 to 2004 . Since then, overseas migration increased to 123,800 persons in $2004 / 05$ and 134,600 persons in $2005 / 06$. As it is expected that net overseas migration will rise further to 175,000 persons in $2006 / 07$ and 185,000 in 2007/08 (BIS Shrapel, 2007), this should drive a further push in demand for dwellings in Sydney. Table 3 shows the intended destination of the migrants and as can be noted, $35.6 \%$ or 64,000 net migrants in 2005/06 settled in NSW. The reasons of its insignificance in this regression model needs to be further studied, as Omar and Ruddock (2002) have suggested that a policy of housing development should take into account both the long-term and short-term trends in population changes and housing demand.

Table 3: Intended state and territory destinations of permanent additions

\begin{tabular}{|r|c|c|c|}
\hline & $1996 / 97$ & \multicolumn{2}{|c|}{$2005 / 06$} \\
\cline { 2 - 4 } & $\%$ & $\%$ & $' 000$ \\
\hline NSW & 43.7 & 35.6 & 64 \\
VIC & 21.7 & 25 & 45 \\
QLD & 15.8 & 17.1 & 30.7 \\
SA & 3.8 & 6.6 & 11.9 \\
WA & 11.6 & 12.4 & 22.3 \\
Other & 2.3 & 2.6 & 47 \\
\hline
\end{tabular}

(Source: ABS, 2007)

\section{CONCLUSIONS}

This paper undertook an empirical study to identify the main determinants that drove Sydney dwelling prices upwards from 1992. Drawing from the literature, various variables were selected and tested. Several models were tested and the paper presented the results of the three most significant models.

Model 3 satisfied all the relevant statistical criteria and was selected as the preferred model. Accordingly, the results identified the main variables that influenced dwelling prices in Sydney from 1992 to 2006. The findings suggest that the real household income, dwelling completions, speculation and real interest rates were the main variables influencing house prices in Sydney over that period. The presented findings of dwelling price determinants are consistent with other findings from the literature and provide a foundation to build on the theory of house price.

For policy purposes, the government is limited as it only indirectly influences household income, interest rates and speculation. However, the government does have a direct influence on increasing the number of completions by releasing more land for new 
housing and as noted, with the growing population, there is a need for policy makers to take this action.

Finally, the paper also recognised that whilst immigration did not have any statistical significance in the three preferred models, it does have a role to play. The limitation of the model used in this paper may be due to it being a linear regression model. Accordingly, further study may be beneficial so as to develop a non-linear model, which may overcome the problem.

\section{REFERENCE}

Abraham, J. M. \& Hendershott, P. H. (1996). Bubbles in metropolitan housing markets. Journal of Housing Research, 7, 191-207.

Australian Bureau of Statistics. (2006). Retrieved 20 March, 2007, from http://www.abs.gov.au/Ausstats

Barker, K. (2003). Review of housing supply - securing our future housing needs: London:Correspondence and Enquiry Unit, HM treasury.

BIS Shrapel. (2007). Building Industry Prospects. Paper presented at the March 2007 Conferences Building Industry Prospects, Sydney.

Bloch, B. (1997). Volatility in the residential house market: an international perspective. Property Management, 15(1), 12-24.

Brown, J. P., Song, H. \& McGillivray, A. (1997). Forecasting UK house prices: a time varying coefficient approach. Economic Modelling, 14, 529-548.

Case, K. E. \& Shiller, R. J. (1990). Forecasting prices and excess returns in the housing market. AREUEA Journal, 18(3), 253-273.

Christopher, L. (2006). Australian Property Monitors. Retrieved 12 April, 2007, from http:/homepriceguide.co.au/media_release/homepriceguide.pdf.

Dieleman, F. M., Clark, W. A. V. \& Deurloo, M. C. (2000). The geography of residential turnover in twenty-seven large US metropolitan housing markets, 1985-95. Urban Studies, 37(2), 223-245.

DiPasquale, D. \& Wheaton, W. C. (1994). Housing market dynamics and the future of housing prices. Journal of Urban Economics, 35, 1-27. 
Dusansky, R. \& Wilson, P. W. (1993). The demand for housing: theoretical considerations. Journal of Economic Theory, 61, 120-138.

Gallin, J. (2003). The Long-Run Relationship between House Prices and Income: Evidence from Local Housing Markets FEDS Working Paper No. 2003-17 Retrieved 03 May, 2007, from http://papers.ssrn.com/sol3/papers.cfm?abstract id $=410808$

Ganesan, S. (1984). Property cycle: theoretical apexes and empirical observation on Hong Kong. Hong Kong: University of Hong Kong.

Goodman, A. C. (1989). The economics of housing market: Switzerland: Harwood Academic Publishers.

Goodman, A. C. (2002). Estimating equilibrium housing demand for "stayers". Journal of Urban Economics, 51, 1-24.

Grimes, A., Kerr, S., \& Aitken, A. (2004). Bi-directional impacts of economic, social and environmental changes and the New Zealand housing market: Motu Economic and Public Policy Research, NZ.

HIA. (2007). Affordability Report. ACT Australia: Commonwealth Bank.

Ho, W. K. O. (2000). Modelling speculative activity in the Hong Kong residential property market. Review of Urban \& Region Development Studies, 12(2), 137-148.

Hui, E. C. \& Ho, V. S. (2002). Relationship between the land-use planning system, land supply and housing prices in Hong Kong. Hong Kong: Hong Kong Polytechnic University Central

Ito, T. \& Hirono, K. (1993). Efficiency of the Tokyo housing market.Unpublished manuscript, Cambridge.

Keynes, J. M. (1936). The Principle of Effective Demand. The General Theory of Employment, Interest and Money Retrieved 13 April, 2007, from http://www.oikonomia.it/pages/megg/classica.htm

Levin, E. J. \& Wright, R. E. (1997a). The impact of speculation on house prices in the United Kingdom. Economic Modelling, 14, 567-585.

Ley, D. \& Tutchener, J. (2001). Immigration, globalization and house price in Canada's gateway cities. Housing Studies, 16, 199-223.

Lum, S. K. (2002). Market fundamentals, public policy and private gain: house price dynamics in Singapore. Journal of Property Research, 19(2). 
Maclennan, D. (1982). Housing economics - an applied approach. London: Longman Group Limited.

MaCurdy, T. (2005). Regional Economic Outlook Sacramento Region [Electronic Version]. California Policy Review, 2005. Retrieved 15 May 2007 from http://www.sphereinstitute.org/publications/CPR_Summer05.pdf.

Malpezzi, S. (1999). A simple error correction model of house prices. Journal of Housing Economics, 8, 27-62.

Megbolugbe, I. F. \& Chao, M. (1993). An empirical analysis of metropolitan housing and mortgage markets. Journal of Housing Research, 4(2), 191-210.

Millington, A. F. (1994). An introduction to property valuation (4th ed.): London: Estate Gazette.

Muellbauer, J. \& Murphy, A. (1997). Booms and busts in the UK housing market. Economic Journal, 197, 1701-1727.

Omar, A. A., \& Ruddock, L. (2002). The internal and external influence in housing markets [Electronic Version], 222-233. Retrieved 18 May 2003 from http://www.scri.salford.ac.uk/bf2002/pdf/omar.pdf.

Osborne, H. (2006). House prices rise again. Retrieved 15 May, 2007, from http://money.guardian.co.uk/houseprices/story/0,1866703,00.html.

Painter, G. \& Redfearn, C. (2002). The role of interest rates in influencing long-run homeownership. Journal of Real Estate Finance and Economics, 25(2/3).

PCA. (2007). Australia's land supply crisis. Sydney: Property Council of Australia.

Peng, R., \& Wheaton, W. C. (1994). Effect of restrictive land supply on housing in Hong Kong: an econometric analysis. Journal of Housing Research, 15(2), 263-292.

Pollak, R. A. \& Wale, T. J. (1981). Demographic variables in demand analysis. Econometrica, 49(6).

QMS. (2004). Eviews 5 User's Guide: Quantitative Micro Sofeware, LLC.

Reichert, A. K. (1990). The impact of interest rates, income and employment upon regional housing prices. Journal of Real Estate and Economics, 3, 373-391. 
Statistics, A. B. o. (2007). Purchasing Power [Electronic Version]. Retrieved 20 Aug 2007 from http://www.abs.gov.au/AUSSTATS/.

Stead, A. (2006). Demand and supply imbalance fuelling house price growth: hometrack. Retrieved 15 April, 2007, from http://www.abcmoney.co.uk/news/0220062619.htm

Tse, R. Y. C., Ho, C. W. \& Ganesan, S. (1999). Income elasticity of housing consumption in Hong Kong: a cointegration approach. Journal of Property Research, 16(2), 123-138.

Tse, R. Y. C. \& Love, P. E. D. (2000). Measuring residential property values in Hong Kong. Property Management, 18(5), 366-374.

\section{Appendix 1: Non-normality test - (Histogram - Normality test)}

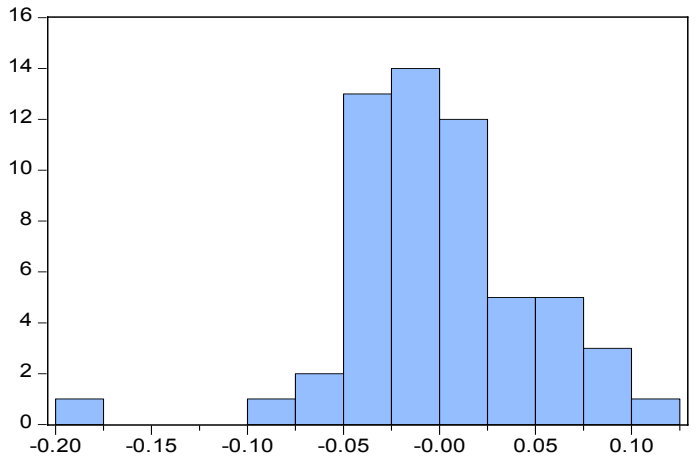

Series: Residuals

Sample 1992Q1 2006Q1

Observations 57

Mean $\quad-0.000112$

Median $\quad-0.002469$

Maximum $\quad 0.101059$

Minimum $\quad-0.188725$

Std. Dev. $\quad 0.049290$

Skewness $\quad-0.516714$

Kurtosis $\quad 5.511583$

Jarque-Bera $\quad 17.51805$

Probability $\quad 0.000157$

\section{Appendix 2: Heteroscedasticity test}

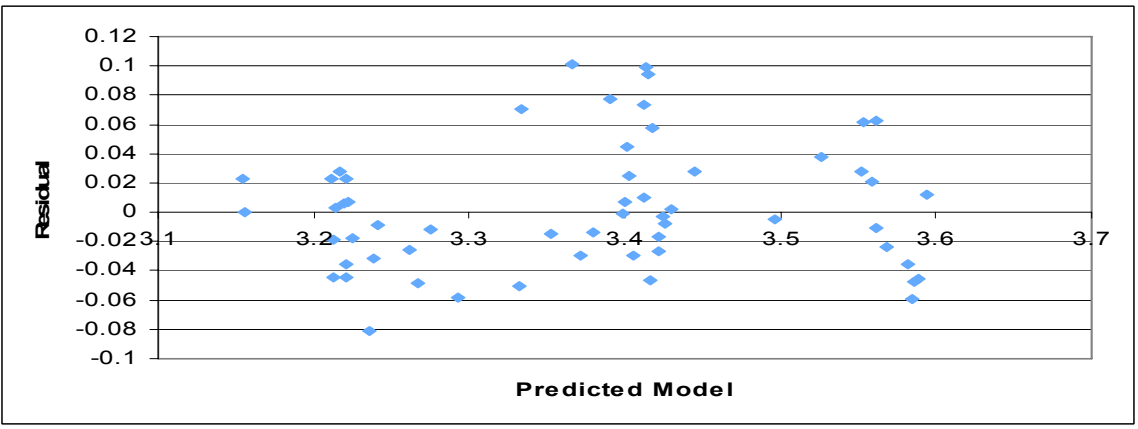


Appendix 3: Test of non-independence of the error variable

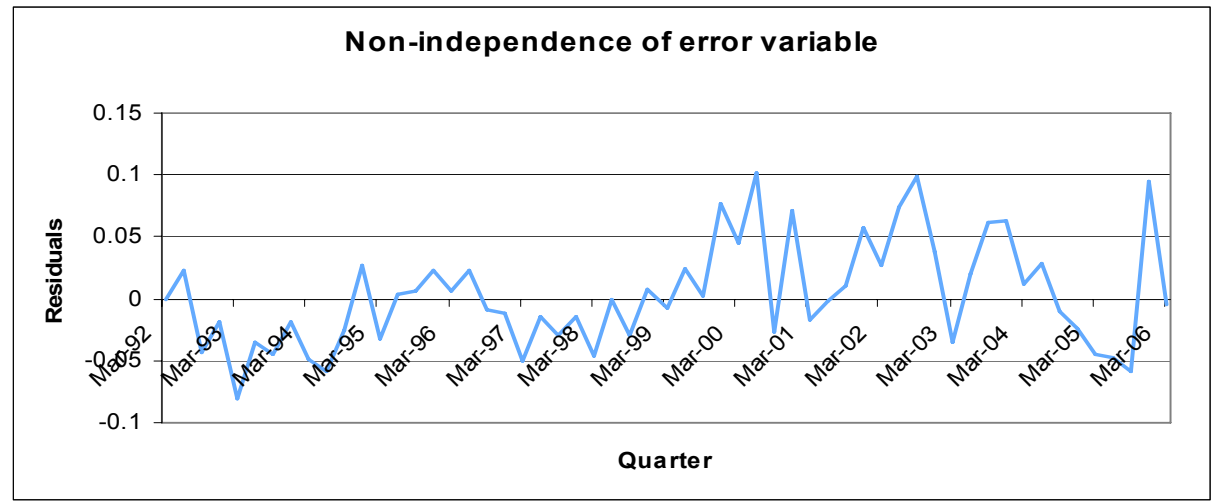

